\section{MODELOVÁNÍ ACIDOBAZICKÉ ROVNOVÁHY PODLE BILANČNÍHO PRINCIPU}

\section{Jiří Kofránek, Filip Ježek}

\begin{abstract}
Abstrakt
V klinickém hodnocení acidobazické rovnováhy se dnes uplatňují dva prístupy. Tzv. klasický prístup „dánské školy“ Siggaard-Andersena a jeho spoluautorů a tzv. moderní prístup dle Stewarta a Fencla. Bilanční př́stup, o kterém jsme hovořili na minulém semináři MEDSOFT, obě teorie propojuje. Pomocí simulačního modelu je možné simulovat různé patogeneze acidobazických poruch a sledovat jejich projevy jak z pohledu klasické, tak i moderní teorie acidobazické rovnováhy.
\end{abstract}

\section{Klíčová slova}

Acidobazická rovnováha, Bilanční přistup, Dánská škola acidobazické rovnováhy, Model, Stewartova teorie

\section{1 Úvod}

Pro vyhodnocování acidobazické rovnováhy (ABR) dnes existují dva př́stupy - klasické pojetí podle dánské školy Astrupa, Siggaard Andersena a dalších, využívající BE a kompenzační diagramy, a Stewartovo pojetí, někdy udávané jako "moderní, založené na fyzikálně chemických výpočtech acidobazických a elekroneutrálních rovnovah iontů a pufrů v plazmě. Obě teorie popisují v zásadě stejnou problematiku pouze z různých aspektů [1-3]. Nicméně mezi příznivci obou teorií někdy vypukají ostré polemiky. Např́klad Kamel a Halperin ve své poslední monografii [4] dovozují, že pro vyhodnocování ABR stačí klasická teorie, rozšířená o korekční výpočty iontových bilancí a Stewartův prístup nepřináší zásadně nic nového. Naproti tomu mnozí jiní autoři považují Stewartův přístup za průlomový a rozhořčeně odmítají jeho kritiku. U nás převažují zejména zastánci druhé skupiny [5-8].

Stewart napsal dva články $[9,10]$, které by možná zapadly, kdyby se propagaci a dalšímu rozpracování Stewartových myšlenek nevěnoval Vladimír Fencl, renomovaný profesor z Bostonu, českého původu [11-16]. Proto zvláště v českém prostředí zní jakákoli kritika Stewartovy-Fenclovy teorie téměř svatokrádežně.

My jsme předložili nové pojetí, založené na bilancích, které podle našeho názoru propojuje obě teorie a dává vysvětlení patofyziologickým pochodům při poruchách iontové a acidobazické rovnováhy $[17,18]$.

Pro verifikaci této teorie (a přesvědčení kliniků) vyvíjíme webově přístupný simulátor, který umožní interaktivně vysvětlit náš prístup.

\section{V čem je Stewartova teorie mylná?}

Bilanční pojetí umožní patofyziologické vysvětlení změn acidobazických parametrů a iontů, které Stewartova teorie vysvětluje mylně a klasická teorie nedostatečně.

Základní slabinou Stewartova přístupu je záměna matematické kauzality (která umožňuje vypočitat $\mathrm{pH}$, a plazmatickou koncentraci bikarbonátů ze vstupních proměnných pCO2, SID a celkové koncentrace nebikarbonátových pufrů $\left.\left[A_{\text {tot }}\right]\right)$ za kauzalitu patofyziologickou (viz Obr 1). Vysvětlení patofyziologie acidobazických poruch mechanistickým přejímáním závislosti $\mathrm{pH}$ a $\mathrm{HCO}_{3}^{-}$na vstupních proměnných $\mathrm{pCO}_{2^{\prime}}$ SID a $A_{\text {tot }}$ je zdánlivě jednoduché, ale nevystihuje skutečný kauzální řetězec vzniku těchto poruch.

Samozrejmě změny SID, $A_{\text {tot }}$ nebo $p C O 2$ se projeví změnou $\mathrm{pH}$ i koncentrace bikarbonátů. Z toho ale nevyplývá, že organismus říi $\mathrm{pH}$ a hladinu bikarbonátů prostřednictvím regulací bilance silných iontů a následným ovlivněním SID nebo regulací hladiny albuminů a fosfátů a následným ovlivnění $A_{\text {tot }}$. Udržování stálosti vnitřního prostředí závisí na bilanci jednotlivých komponent, které vnitřní prostředí (tj. složení ECT) tvoří. lontová, objemová, a osmotická homeostáza vnitřního prostředí závisí na regulované bilanci jednotlivých látek (iontů, vody aj.). Acidobazická homeostáza není výjimkou. Opět se jedná o regulaci bilancí toků látek - toků $\mathrm{CO}_{2^{\prime}} \mathrm{H}^{+}$a $\mathrm{HCO}_{3}^{-}$. Díky bikarbonátovému pufračnímu systému v tělních tekutinách jsou toky $\mathrm{CO}_{2}, \mathrm{H}^{+}$ a $\mathrm{HCO}_{3}$ - vzájemně propojené.

Tok $\mathrm{CO}_{2}$ rídí respirace - poruchy bilance $\mathrm{CO}_{2}$ vedou k respiračním poruchám acidobazické rovnováhy. Nicméně nesmíme zapomínat na to, že hladina $\mathrm{CO}_{2}$ ve venózní krvi, a s ní ekvilibrované IST, závisí nejen na arteriální koncentraci závislé na respiraci, ale také na perfúzi - v hypoperfundovaných tkáních dochází k hyperkapnické acidóze i při normálních acidobazických poměrech v arteriální krvi (hyperkapnická hypoperfúzní tkáňová acidóza vede $\mathrm{k}$ vazbě $\mathrm{H}^{+}$na bílkoviny $v$ buňkách $\mathrm{s}$ poškozením funkčnosti příslušných enzymů). Za normálních okolností je metabolická tvorba $\mathrm{H}^{+} \mathrm{v}$ rovnováze s tokem bikarbonátů generovaným ledvinami při acidifikaci moči. Poruchy bilance toků $\mathrm{H}^{+} / \mathrm{HCO}_{3}^{--}$vedou k metabolickým poruchám acidobazické rovnováhy.

Organismus tedy neřídí pH tělních tekutin a hladinu $\mathrm{HCO}_{3}^{-}$pomocí změny SID a regulací hladiny albuminů, nýbrž regulací bilance toků $\mathrm{CO}_{2}$ (respirační regulace $\mathrm{ABR}$ ) a $\mathrm{H}^{+}$

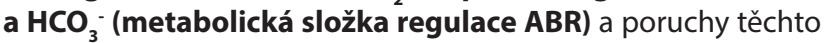
bilancí vedou k acidobazickým poruchám. Bilanční teorie přináší patofyziologické vysvětlení přičin změn iontogramu, SID a $A_{\text {tot }}$ při různých acidobazických poruchách.

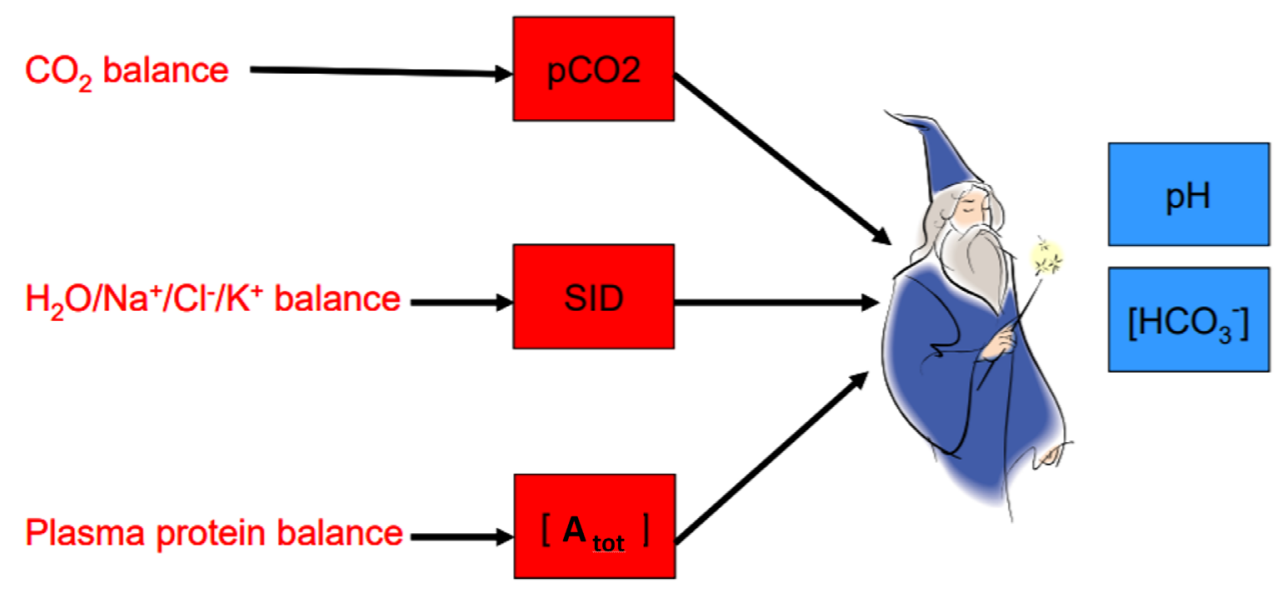




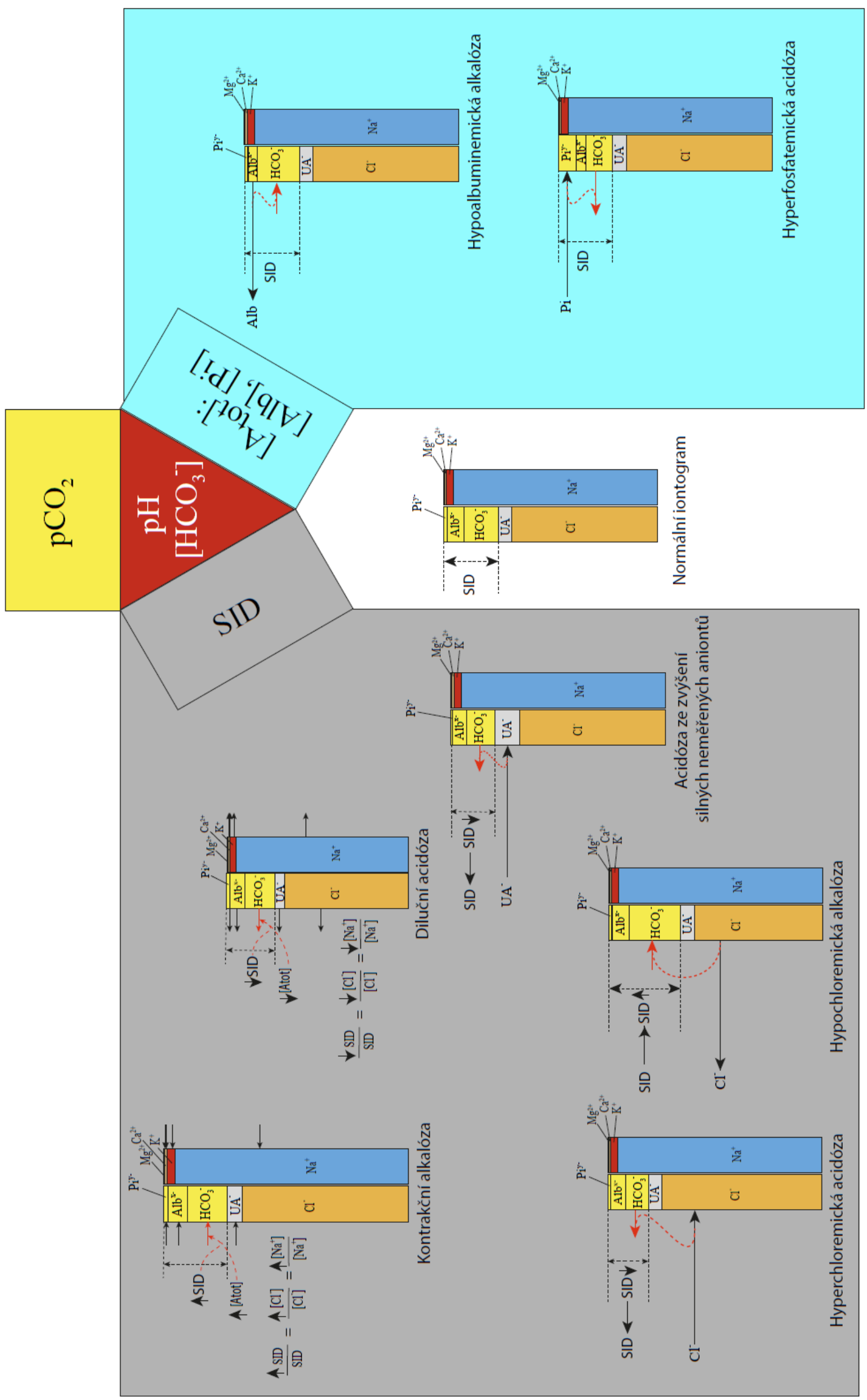

¿

$+\frac{1}{2}$

品

oิ ะ

I

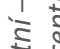




\section{V čem dánská škola vysvětluje patofyziologii ABR poruch nedostatečně?}

Dánská škola se soustřed'uje na diagnostiku poruch ABR především na základě vyšetřování koncentrací složek pufračních systémů v krvi (a odvozeně v ECT) a koncentrací iontů v ECT. Nedostatečně popisuje diagnostiku smíšených poruch (zejména tam kde jsou obě poruchy protichůdné) a především jejich přícin a selhává při hodnocení hemodilučních a hemokoncentračních stavů [18].

\section{Co přináší nového bilanční teorie}

Bilanční pojetí vychází z následujících šesti principů, které umožní patofyziologické vysvětlení změn acidobazických parametrů a iontů (viz část 6 v článku):

1. Veškeré přesuny přes membrány probíhají v ustáleném stavu v celkové bilanci elektroneutrálně.

2. Při biochemických reakcích $v$ lidském organismu se nemění elektroneutralita. Takže napríklad negativně nabitý laktát nebo citrát se metabolizuje na vodu a $\mathrm{CO}_{2}$ za spotřeby $\mathrm{H}^{+}$iontu - tedy jako kyselina mléčná nebo citronová.

3. Acidobazická rovnováha závisí na bilanci toků $\mathrm{CO}_{2}$, protonů a bikarbonátů propojených přes bikarbonátový pufrační systém. To je stejné jako u klasické teorie a umožňuje tak rozdělit poruchy $A B R$ na respirační (bilance $\mathrm{CO}_{2}$ ) a metabolické (bilance $\mathrm{H}^{+} / \mathrm{HCO}_{3}{ }^{-}$).

4. Hodnoty SID a BB v plazmě vyjadřují stejné entity, počítané různým způsobem, změny hodnot SID a $B B$ (BE) jsou totožné a charakterizují bilanci toků protonů a bikarbonátů. Přidání $1 \mathrm{mmol} / /$ protonů snízí SID a BB o $1 \mathrm{mmol} / \mathrm{l}$, přidání $1 \mathrm{mmol} / \mathrm{l}$ bikarbonátů hodnoty SID a BB zvýší o 1 mmol/l (a opačně).

5. Bikarbonátový nárazníkový systém v tělních tekutinách zachycuje nebo uvolňuje protony a toky protonů jsou proto ekvivalentní tokům bikarbonátů.

6. Pufrační systémy jsou "zásobárnami nebo odkladištěmi" při nerovnováze bilance toků bikarbonátů s př́slušnými změnami acidobazické rovnováhy.

Bilanční teorie není založena na hodnocení koncentrace bikarbonátu v ECT, jak by se mohlo na první pohled zdát. Zajímá nás bilance toků $\mathrm{H}^{+} / \mathrm{HCO}_{3}{ }^{-}$a s nimi elektroneutrálně propojených toků ostatních iontů. Toky vodíkových iontů a bikarbonátů jsou propojeny přes bikarbonátový systém, který je všudypř́tomný $v$ tělních tekutinách. Rychlost difúzního toku závisí na gradientu koncentrací. Koncentrační gradient protonů je o mnoho rádů menší než koncentrační gradient bikarbonátů - proto difúzní toky protonů jsou menší než difúzní toky bikarbonátů. Proto je možné acidobazickou metabolickou bilanci charakterizovat bilancí toku bikarbonátů. Negativní bilance bikarbonátů charakterizuje metabolickou acidózu, pozitivní bilance - metabolickou alkalózu - $v$ tom se naše teorie shoduje $s$ klasickou dánskou školou ABR.

Pufrační systémy jsou skutečnými tlumiči výkyvů acidobazických bilancí toků $\mathrm{H}^{+} / \mathrm{HCO}_{3}^{-}$při metabolických poruchách acidobazické rovnováhy. Při negativní nebo pozitivní bilanci bikarbonátů (tj. při metabolické acidóze nebo alkalóze) pufrační systémy poskytují nebo akumulují bikarbonáty a následná změna ekvilibria uvnitř pufračních systémů vede ke změnám pH (viz Obr. 15-18 v článku "Bllanční pojetí acidobazické rovnováhy" z minulého Medsoftu - článek je přistupný online na adrese http://www.creativeconnections.cz/medsoft/2017/ Medsoft 2017 Kofranek1.pdf) [18]).
Z hlediska bilancí není podstatná jen koncentrace jednotlivých složek pufrů, ale i celkové množství.

Klasická nebo Stewartova teorie ABR pracují převážně s koncentracemi látek, což někdy vede k mylným závěrům. $Z$ hlediska fungování pufračních systémů jako tlumičů výkyvů bilancí toků $\mathrm{H}^{+} / \mathrm{HCO}_{3}^{-}$při metabolických poruchách $A B R$ není podstatná jen koncentrace, ale i celkové množství pufračních bází - tj. zejména bikarbonátů v ECT. Jak např. upozorňuje Halperin a Kamek $[4,19]$, při snižení objemu ECT se sniží i celkové množství bikarbonátů, které mohou vazbou $\mathrm{H}^{+}$tlumit výkyvy bilance $\mathrm{H}^{+}$/ $\mathrm{HCO}_{3}^{-}$při metabolických acidózách. Při sníženém objemu ECT pokles koncentrace bikarbonátů, resp. pokles BE (nebo SID) nemusí odpovídat tíži metabolické acidózy.

Kamel a Halperin [4] dále upozorňují na roli zásob bikarbonátů $v$ ECT pro prevenci vazby vodíkových iontů na proteiny mozkové tkáně při metabolických acidózách Bikarbonáty v ECT, zejména v ECT svalové tkáně, př̀ acidózách vážou nálož vodíkových iontů, a mozková tkáň, kde je relativně málo $\mathrm{HCO}_{3}$, ale protéká jí značná část krevního průtoku, váže jen minimum vodíkových iontů. $V$ prípadě ohrožení objemu (snížení efektivního objemu arteriální krve) stoupne $\mathrm{pCO}_{2}$ zejména ve svalové tkáni, a mozková tkáň je ohrožena vazbou $\mathrm{H}^{+}$ na proteiny. Rozdíl mezi hladinou $\mathrm{pCO}_{2} v$ arteriální krvi a brachiální véně větší než 6 mmHg svědčí o ohrožení objemu.

Bilanční teorie přináší jiné vysvětlení metabolických poruch acidobazické rovnováhy.

\section{Diluční acidóza a kontrakční alkalóza dle bilančního principu}

Řada autorů např. [20] (ale třeba u nás i Kazda) vysvětloval diluční acidózu po přidání fyziologického roztoku tak, že kvưli relativnímu nadbytku chloridů se sníží SID, a bikarbonát zanikne kvưli elektroneutralitě. Jenomže bikarbonát v pufrační reakci přece zaniká jedině vazbou $\mathrm{s} \mathrm{H}^{+}$a ten se uvolní z nebikarbonátových pufrů $\mathrm{AH}$ - čímž ale zase stoupne negativní náboj $\mathrm{A}$ takže $v$ pufračních reakcích se elektroneutralita nemění a toto vysvětlení je proto špatné.

Skutečná příčina diluční acidózy/kontrakční alkalózy nijak nesouvisí s chloridy - souvisí se zředěním/nebo zakoncentrováním pufrů s tím, že se přitom koncentrace slabé kyseliny $\left(\mathrm{CO}_{2}\right.$ $\mathrm{a}_{2} \mathrm{CO}_{3}$ ) nemění tak jak je naznačeno na Obr. 20 v původní publikaci.

Pufry jako "chemické stroje" udržuji stálé pH, které je závislé na poměru koncentrací slabé kyseliny $[\mathrm{HA}]$ a její konjugované baze $\left.\left[\mathrm{A}^{-}\right]: \mathrm{H}^{+}\right]=\mathrm{Ka}[\mathrm{HA}] /\left[\mathrm{A}^{-}\right]$(Ka je disociační konstanta). Při zředění či zakoncentrování se koncentrace slabé kyseliny a její konjugované baze mění stejně - podíl jejich koncentrací zůstává stejný a proto se $\mathrm{pH}$ nemění. $\mathrm{V}$ pufračních systémech krve se však koncentrace $\mathrm{CO}_{2}$ a tudiž i koncentrace slabé kyseliny $\mathrm{H}_{2} \mathrm{CO}_{3} \mathrm{v}$ arteriální krvi (a př̀i neměnném průtoku i ve venózní krvi a v tkáních) nemění - a to posouvá rovnováhu v pufračních systémech doprava (při zředění) na kyselou stranu nebo doleva (při zakoncentrování) na zásaditou stranu.

Když přidáme k plazmě fyziologický roztok $\mathrm{NaCl}$ tak vyvolávající příčinou diluce není to, že oproti $\mathrm{Na}^{+}$relativně stoupnou chloridy, ale to, že se zředí pufry (včetně jejich konjugovaných bazí, což se projeví poklesem SID) a nezředí se přitom se koncentrace $\mathrm{CO}_{2}$ a $\mathrm{H}_{2} \mathrm{CO}_{3}$. To se projeví posunem rovnováhy uvnitř pufračního systému v plazmě - poklesem koncentrace $\mathrm{HCO}_{3}$. a odpovídajícím vzestupem koncentrace nebikarbonátových bazí, beze změny dilucí sníženého SID resp. BE a poklesem pH). Úplně stejně se projeví diluční efekt, když přidáme krystaloidy (a nezměníme poměr koncentrací $\mathrm{Na}^{+} \mathrm{a} \mathrm{Cl}^{-}$).

$\mathrm{Na}$ atlasu fyziologie (http://www.physiome.cz/atlas/acidobaze/02/ABR v plazme1 2.html) jsme implementovali Wilkesův model [21] a tam je možné si tyto procesy přehrát interaktivně. 


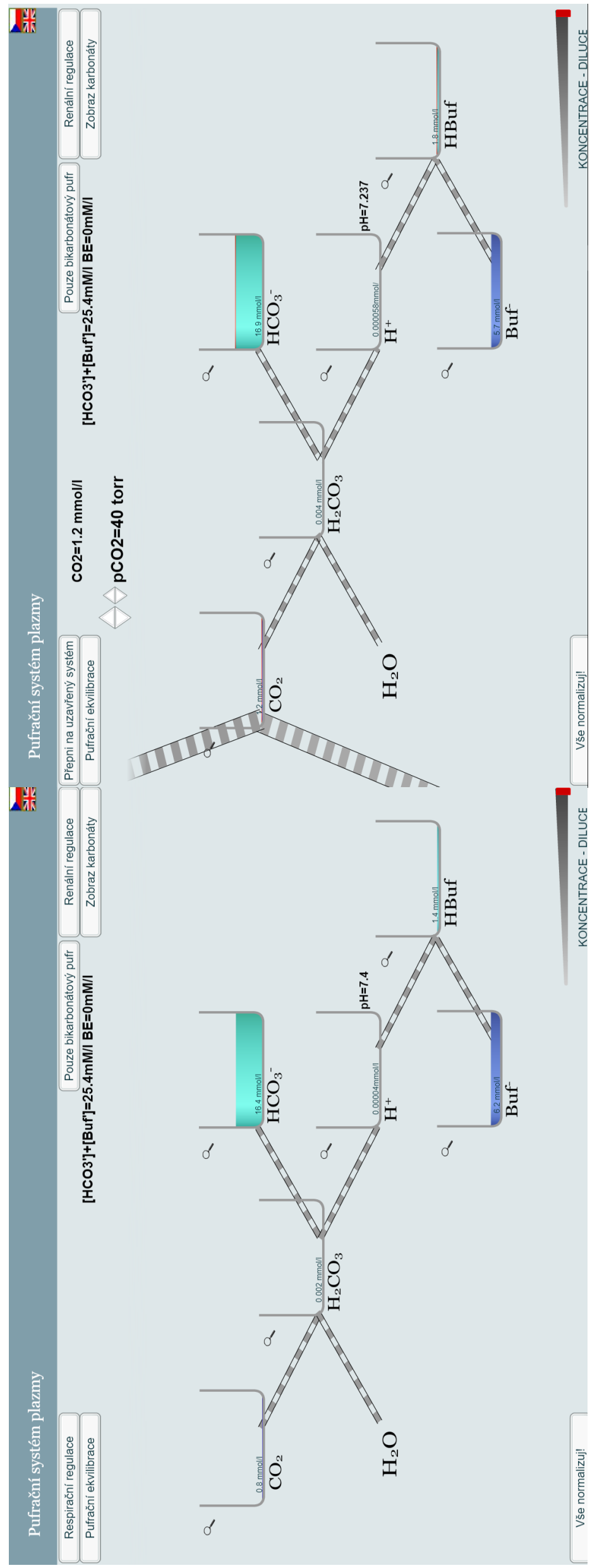

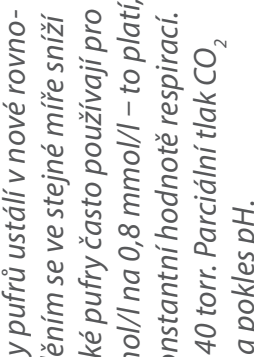

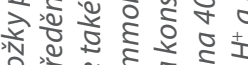

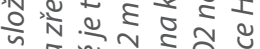

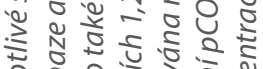

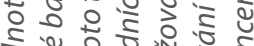

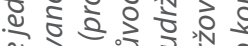

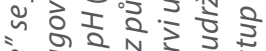

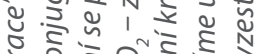

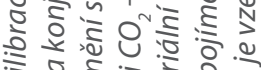

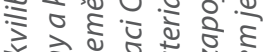

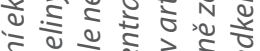

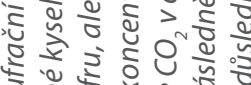

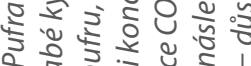

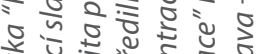

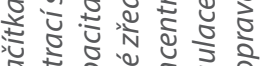

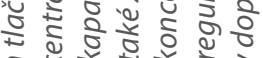
है

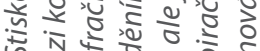

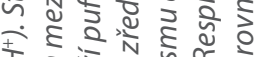

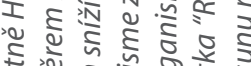

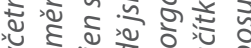

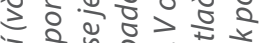

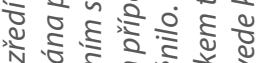

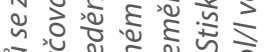

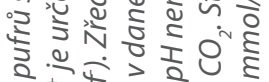

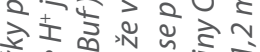

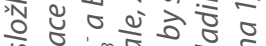

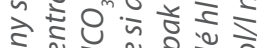
टे ญ्र है 10

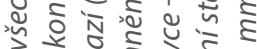

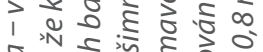

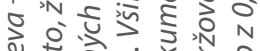

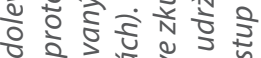

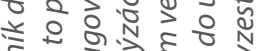
है. 층 है

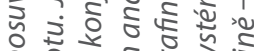

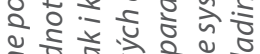
है के 형항 है

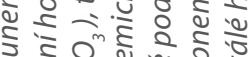
ํํㅇ

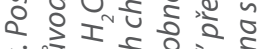
हें

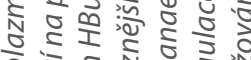

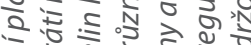

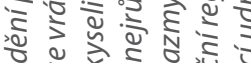
क्षे

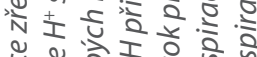

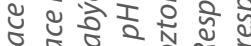

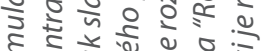

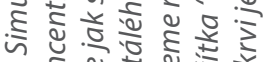

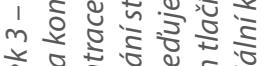

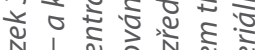

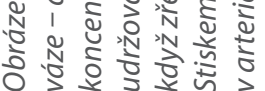



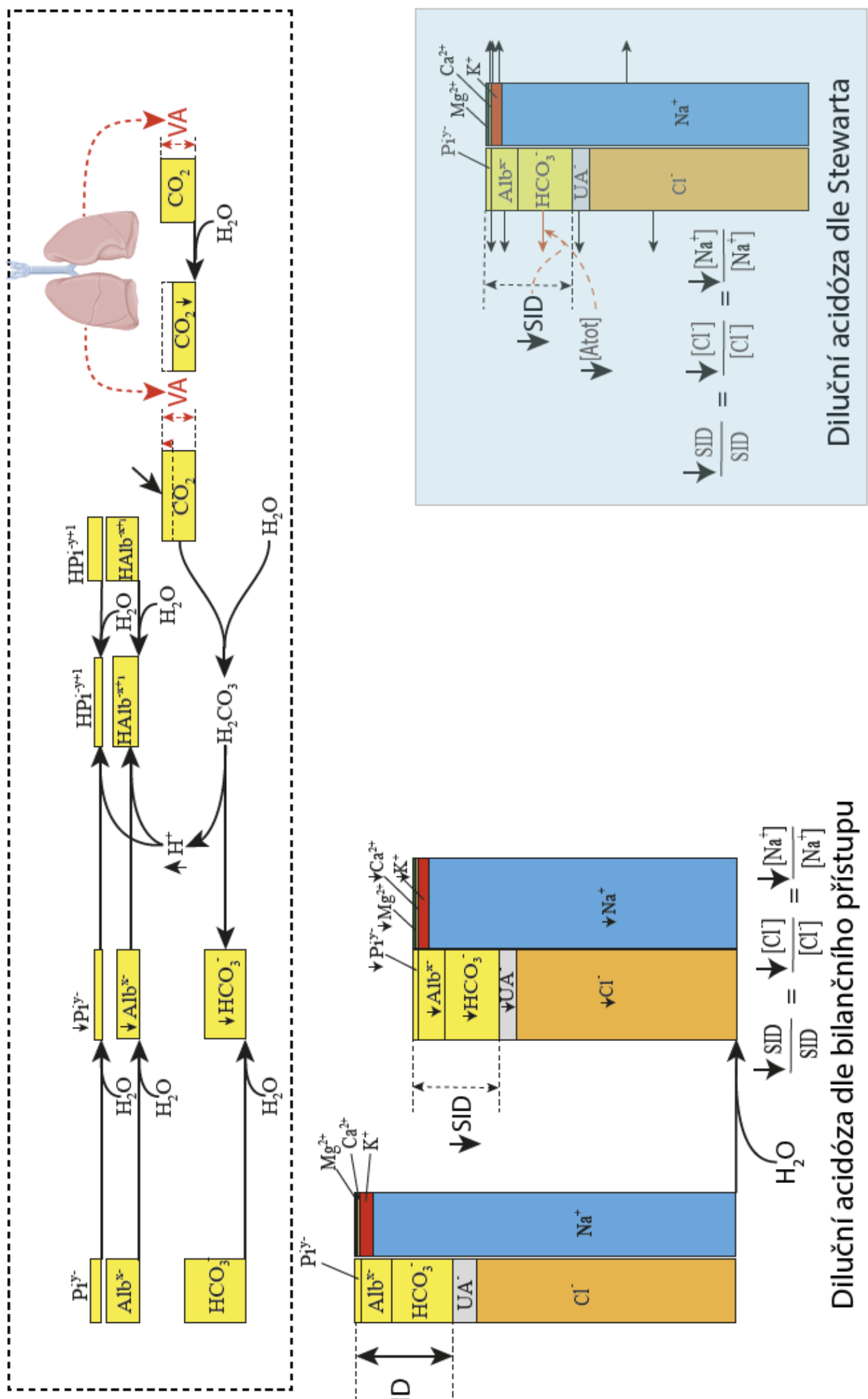

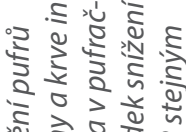

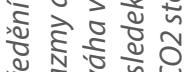

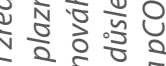

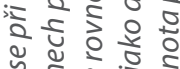

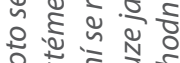

을

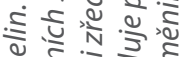

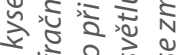

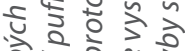

은

$\tilde{n}=\frac{8}{2}, \frac{8}{2}$

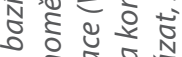

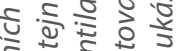

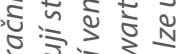

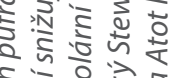

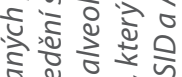

约

วิ

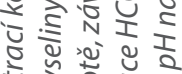

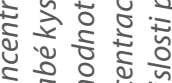

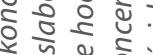

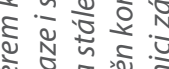

है

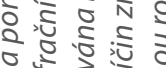

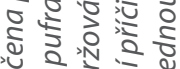

ว $\frac{2}{2}$

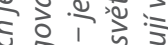

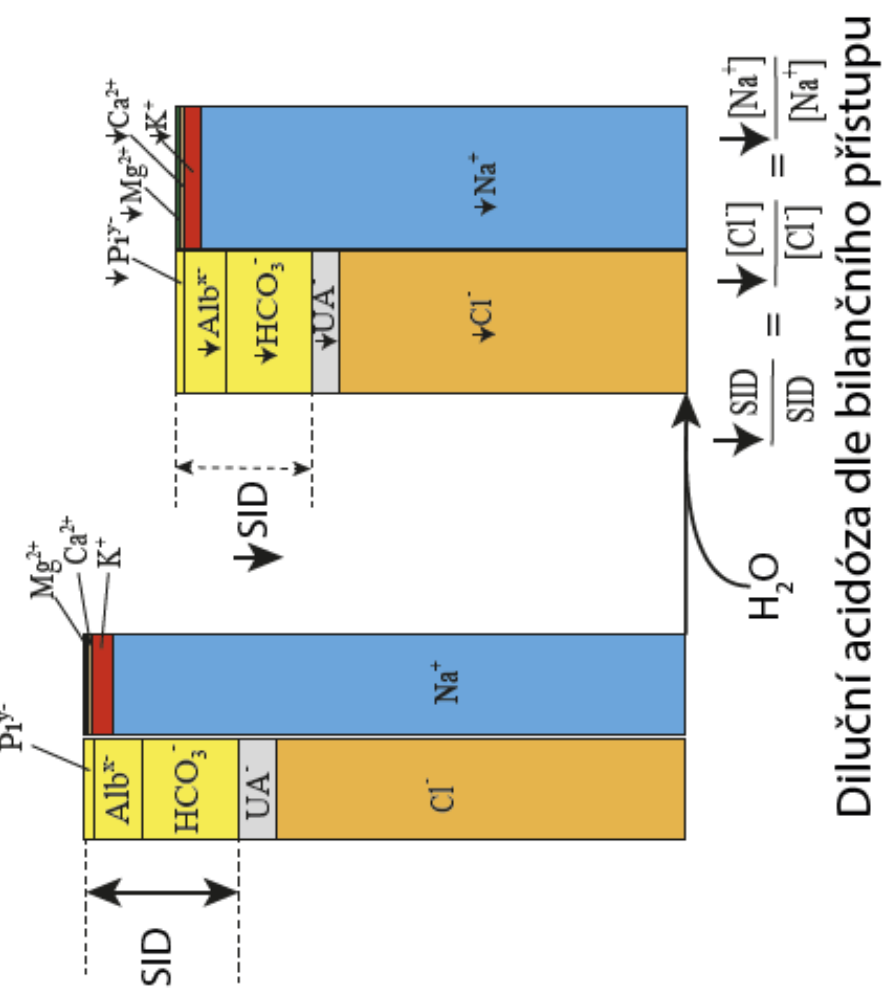

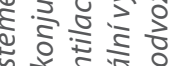

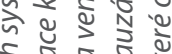

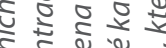

Q

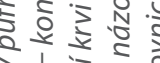

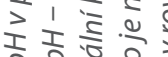

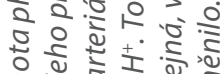

을

오눙

तो

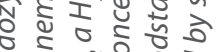

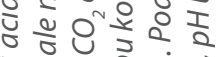

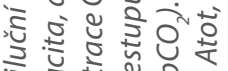

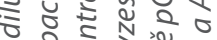

ते 원 $\vec{x}$ ज

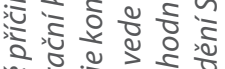

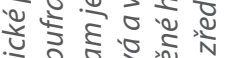

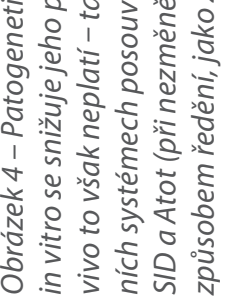



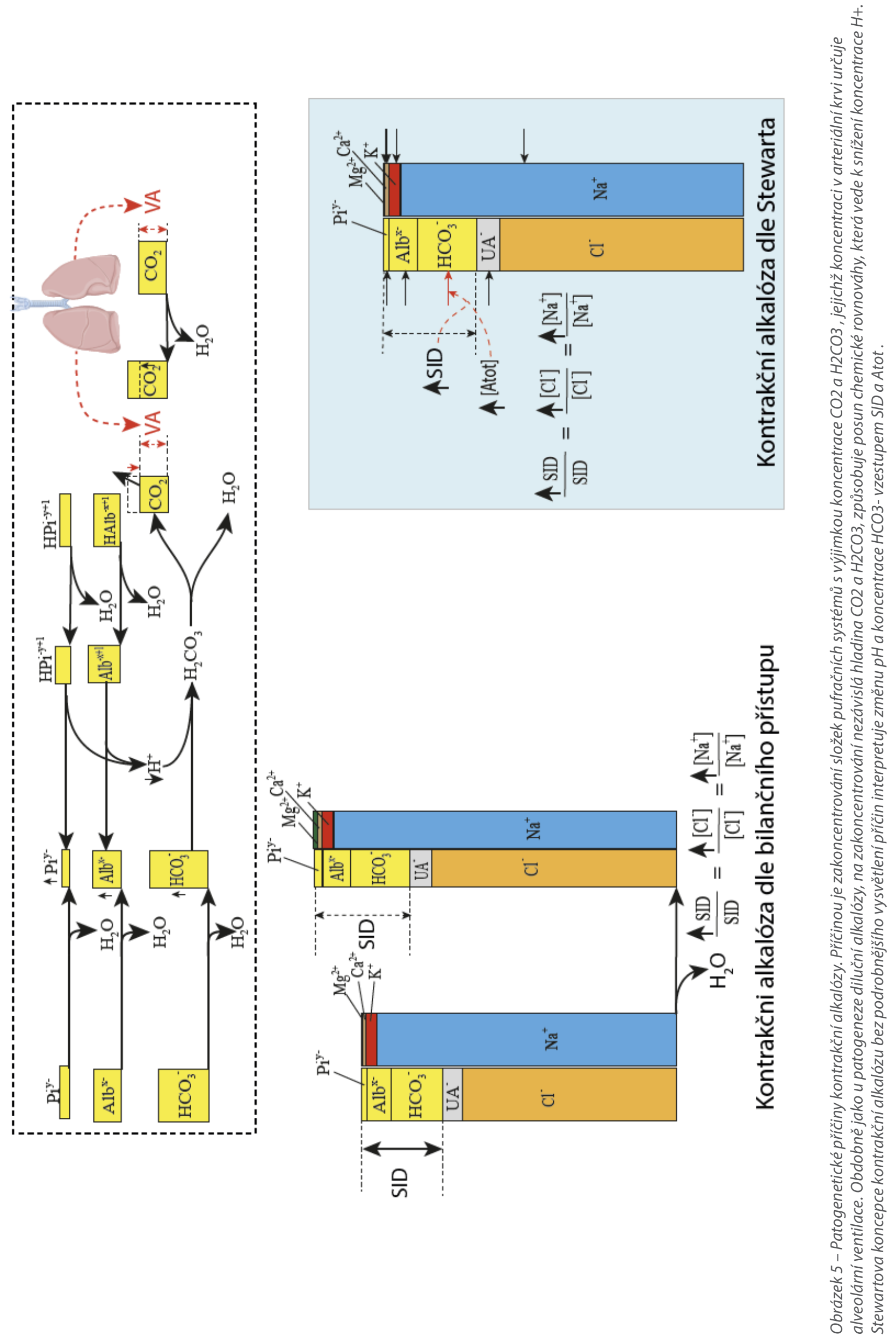

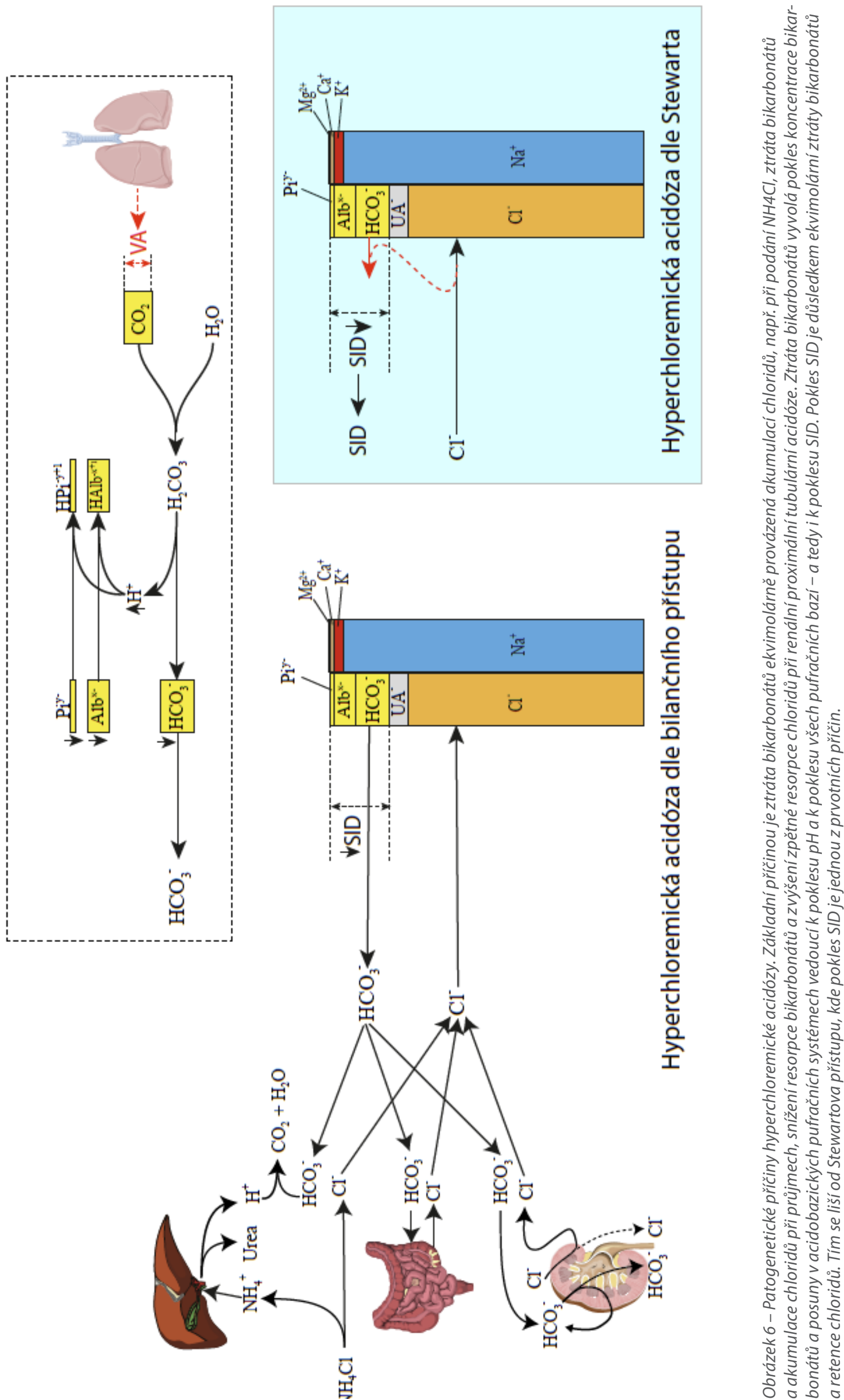


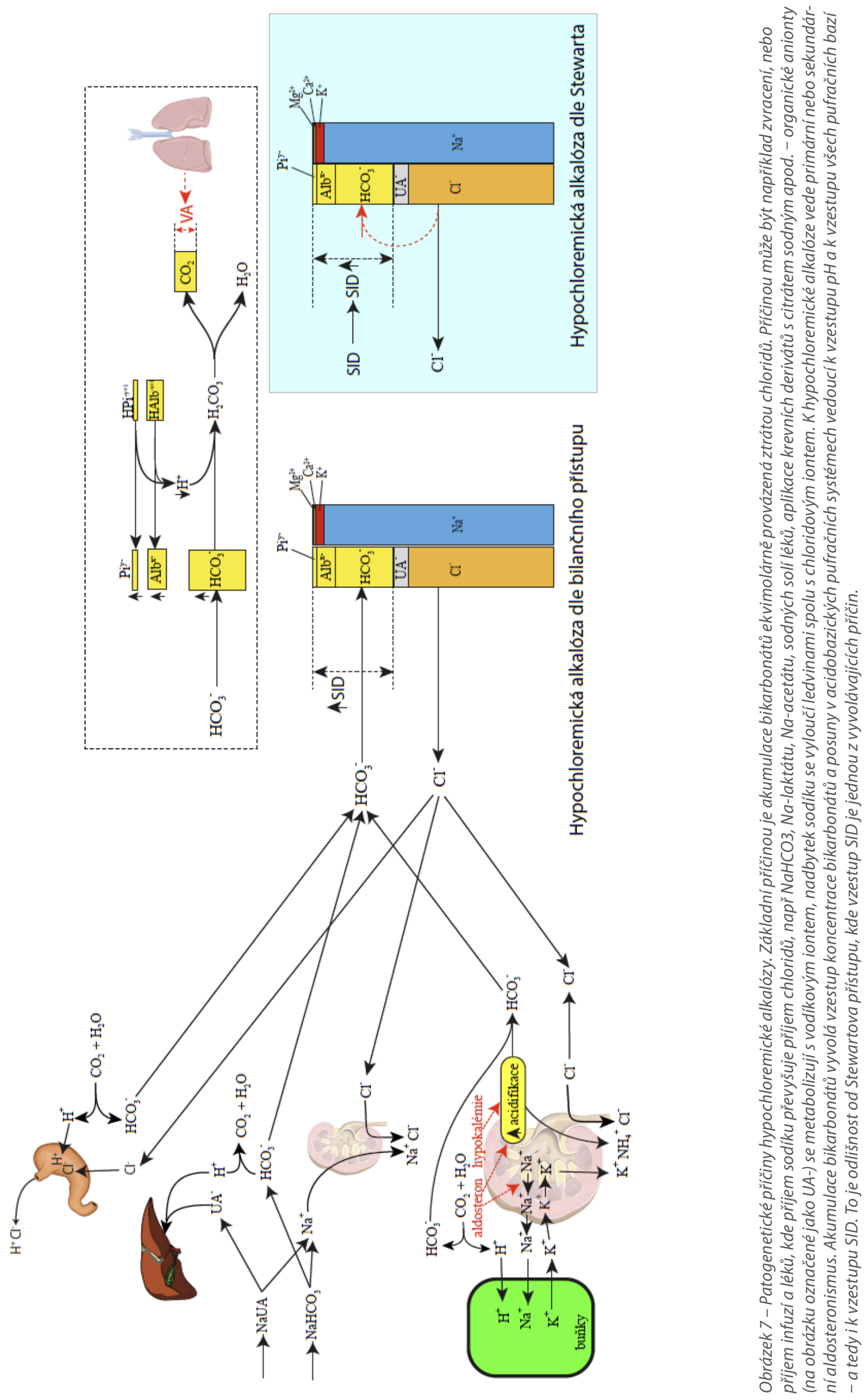



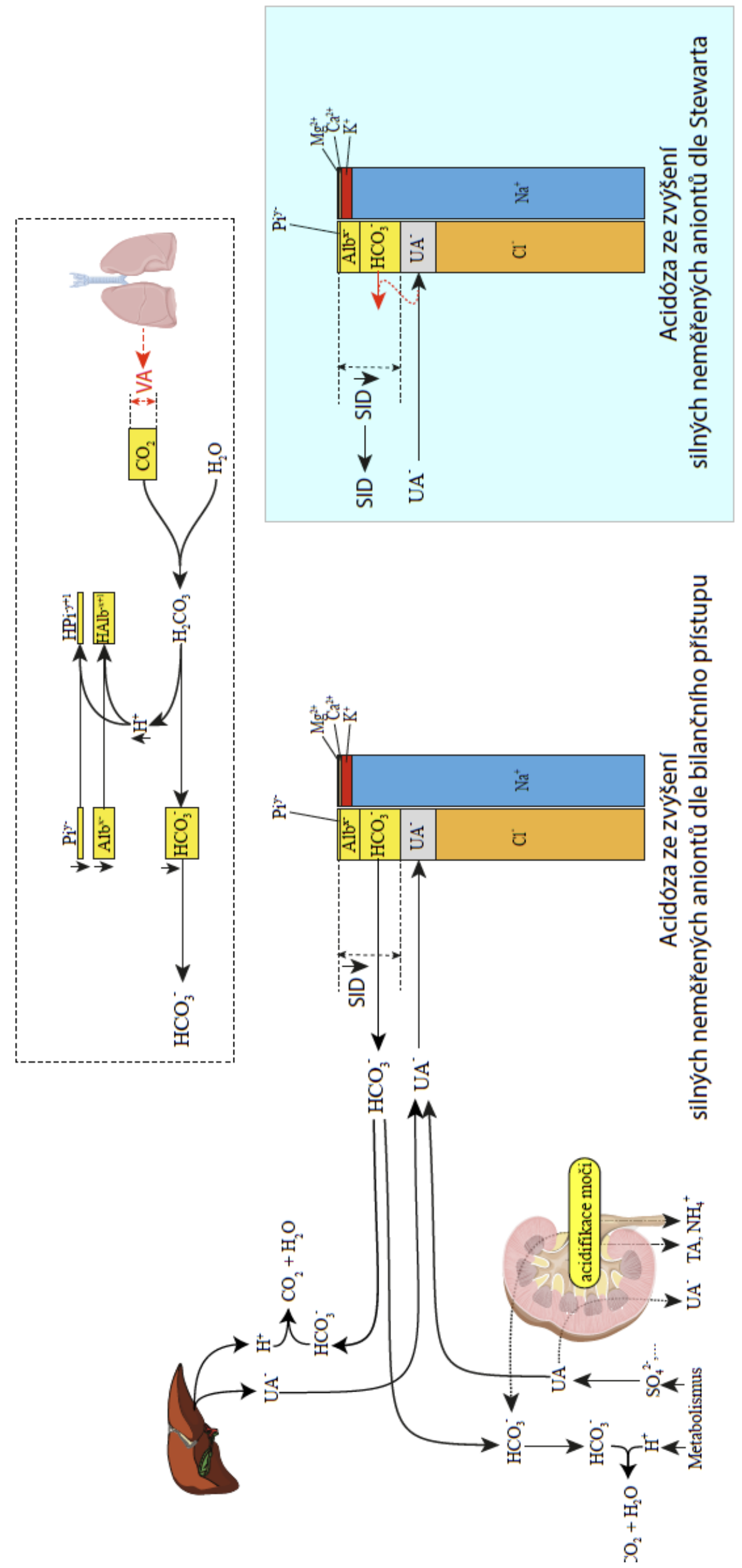

จ่ हैํํำ

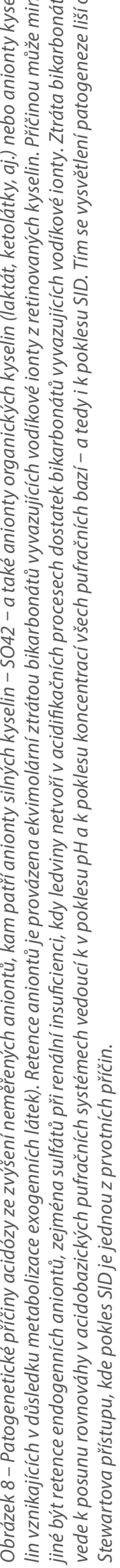




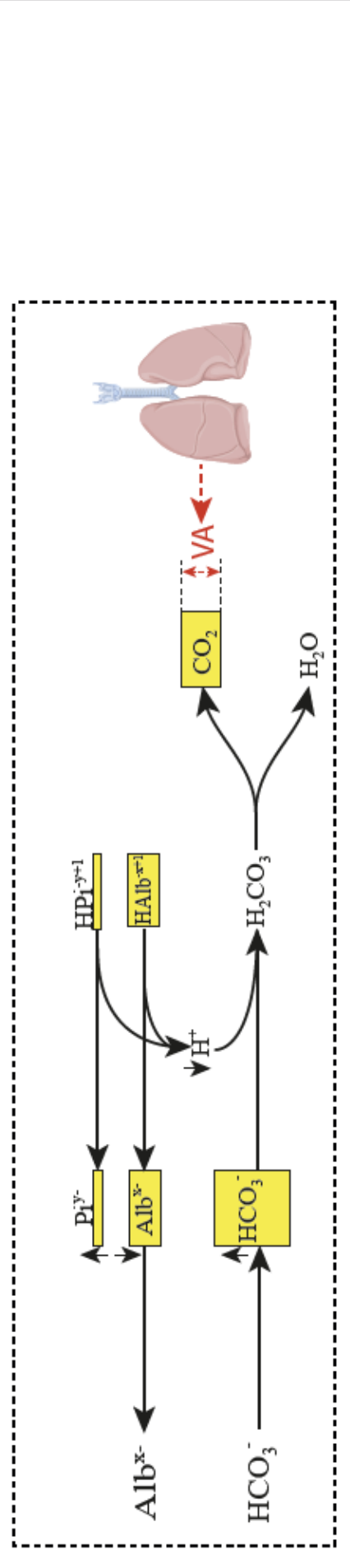

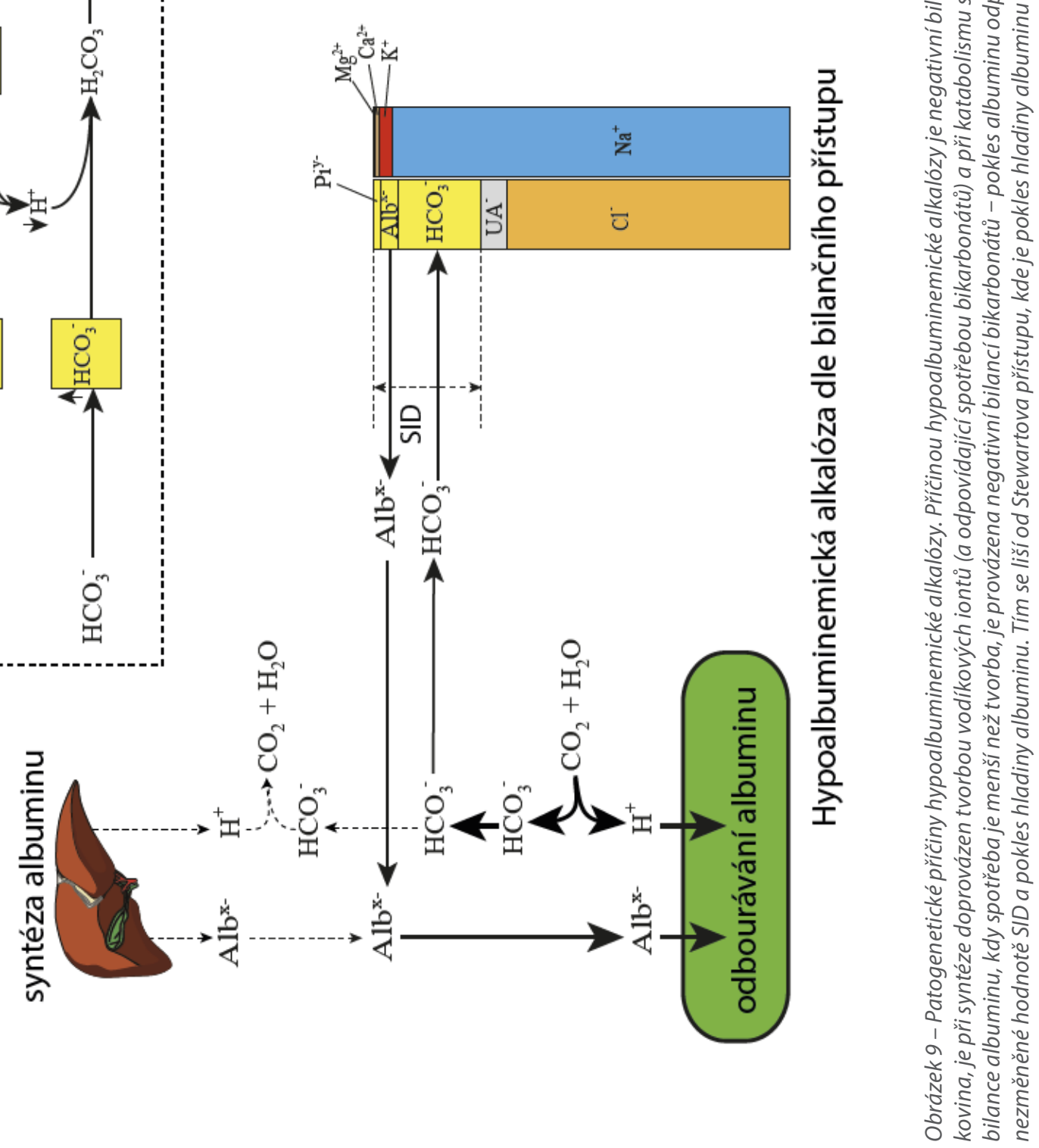

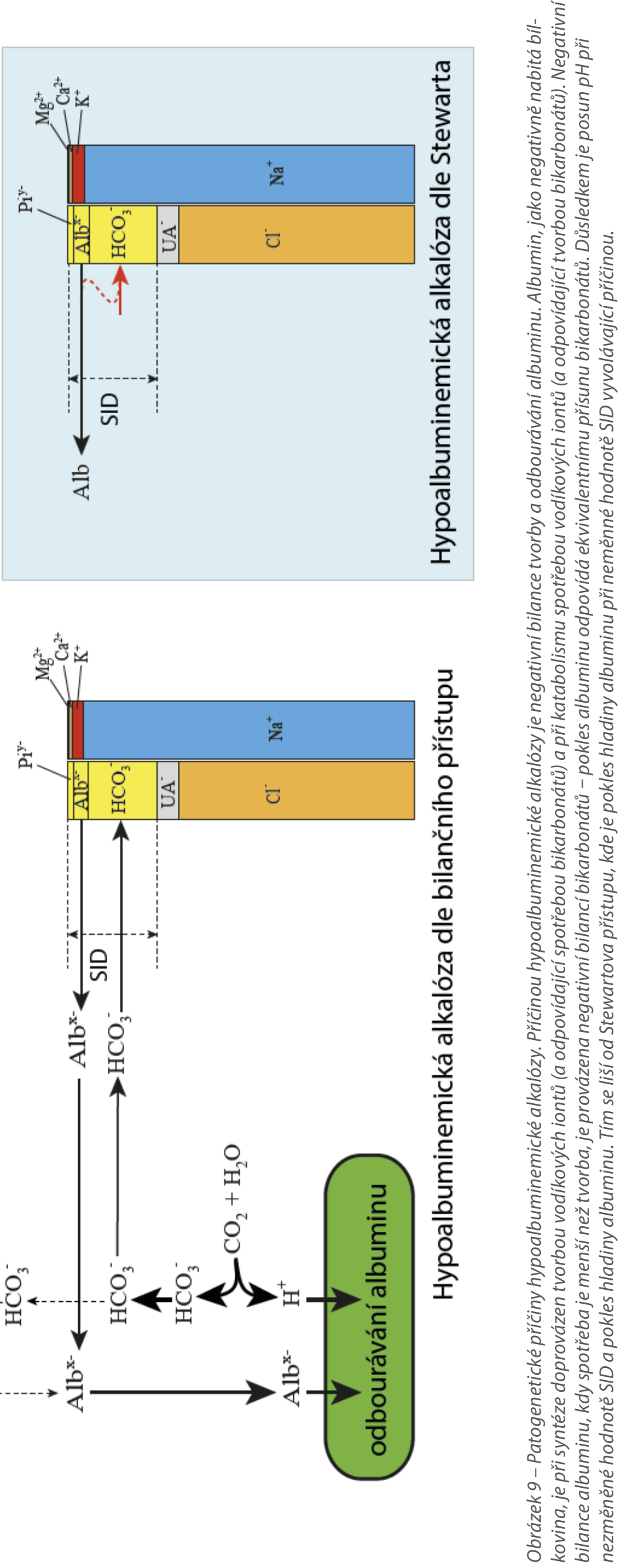



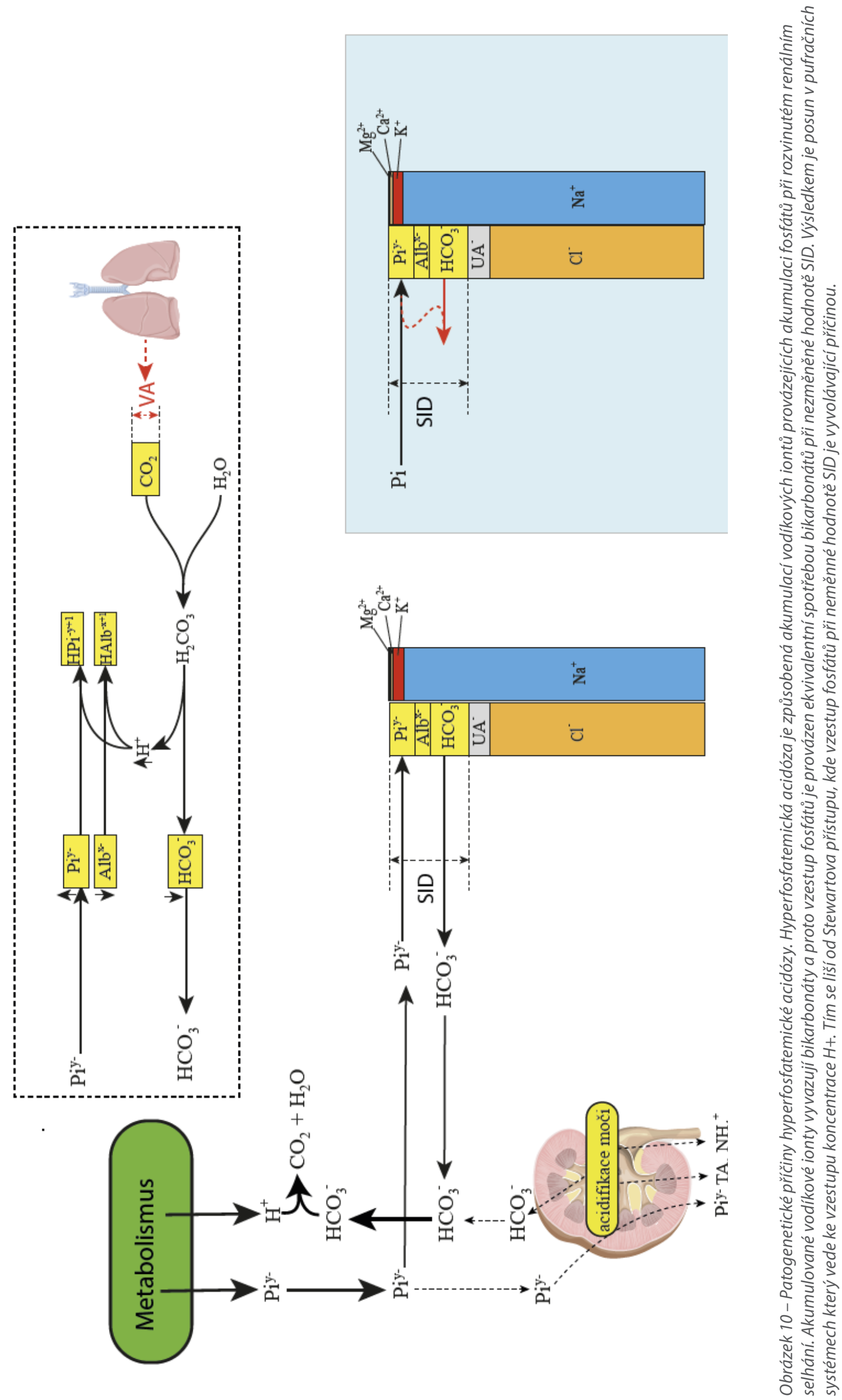
Na rozdíl od modelu plazmy jsou v reálném organismu změny $\mathrm{pH}$ při diluci či hemokoncentraci tlumeny zapojením intracelulárních nárazníků $[22,23]$ a odpovědí ledvin.

Patogenetické vysvětlení diluční acidózy přináší Obr. 4 a patogenetické vysvětlení poruch kontrakční alkalózy je uvedeno na Obr 5.

\section{Patogeneze hyperchloremické acidózy a hypochlore- mické alkalózy}

Patogenetické př́činy hyperchloremické alkalózy zobrazuje Obr. 6. Dle Stewarta se koncentrace bikarbonátů a pH přizpůsobuje SID a pCO2. Dle bilančního přístupu je hladina bikarbonátu určená bilancí ztrát a přísunů bikarbonátu a odpovídající rovnováhou v pufračním systému. Odebrání $1 \mathrm{mmol} / \mathrm{l}$ bikarbonátu neznamená snížení hladiny bikarbonátu o $1 \mathrm{mmol}$ (snižení bude o něco menší, protože se ještě sníží hladiny nebikarbonátových bazí). Odebrání $1 \mathrm{mmol} / \mathrm{l}$ bikarbonátu ale sníží SID o $1 \mathrm{mmol}$.

Příčinou hypochloremické alkalózy dle Stewarta je snížení SID, díky relativnímu vzrůstu koncentrace chloridů. Bikarbonát se tomu přizpůsobí a snízí svou koncentraci. Dle bilančního přístupu je základní př́ičinou akumulace bikarbonátů ekvimolárně provázená ztrátou chloridů (viz Obr. 7).

\section{Patogeneze metabolické acidózy ze zvýšení silných neměřených aniontů}

Patogenetickou přičinou acidózy za zvýšení silných neměřených aniontů je dle Stewarta snížení SID, čemuž se přizpůsobí hladina bikarbonátů, která klesne a proto klesne i pH. Dle bilanční teorie je základní přičinou poruchy retence silných disociovaných kyselin v ECT. Vodíkové ionty se okamžitě vážou na bikarbonát a tím snižují jeho koncentraci. Retence aniontů silných kyselin je proto provázená ekvimolární ztrátou bikarbonátů, které vyvazují vodíkové ionty z retinovaných kyselin (Obr. 8).

\section{Patogeneze hypoalbuminemické alkalózy}

Patogenetickou příčinou hypoalbuminemické alkalózy je negativní bilance tvorby a odbourávání albuminu. Albumin je negativně nabitá bílkovina. Syntéza a odbourávání albuminu je elektroneutrální. Při syntéze je proto vznikající albumin doprovázen vodíkovými ionty (a odpovídající spotřebou bikarbonátů) a při katabolismu albumin elektroneutrálně zaniká v metabolismu spolu vodíkovými ionty (spotřeba vodíkových iontů je provázena tvorbou bikarbonátů). Důsledkem je posun pH při nezměněné hodnotě SID a pokles hladiny albuminu. Tím se výklad dle bilanční teorie liší od Stewartova přístupu, kde je pokles hladiny albuminu při neměnné hodnotě SID vyvolávající príčinou.

\section{Patogeneze hyperfosfatemické alkalózy}

Př́činou hyperfosfatemické alkalózy je akumulace fosfátů spolu s vodíkovými ionty. Vodíkové ionty vyvazují bikarbonáty a proto vzestup fosfátů je provázen ekvimolární spotřebou bikarbonátů při nezměněné hodnotě SID (viz Obr. 10).

\section{Proč vytvářet modely acidobazické rovnováhy dle bilanční přístupu}

Domníváme se že hlavním prínosem bilančního pojetí je kauzální vysvětlení propojení acidobazických a iontových a objemových poruch a pohled na poruchy vnitřního prostředí z hlediska integrativní fyziologie. Souhlasím, že klinik potřebuje fenomenologický popis aktuálního stavu $A B$ rovnováhy k diagnostice i stanovení léčebného postupu. Stewartův přístup nabízí vcelku jednoduché a $v$ praxi použitelné (ale patofyziologicky neúplné) vysvětlení acidobazických poruch pomocí tří nezávislých proměnných. Bilanční pohled umožní pochopit patogenetické příciny Stewartovou metodou popisovaných fenoménů.
Zejména v případě kombinovaných poruch je nutné uvažovat vzájemné souvislosti a poruchy objemu, zásob (nejen koncentrací) jednotlivých komponent a to bez bilančního pohledu nejde.

Pro stanovení nových pohledů na diagnostiku a pro počítávání návrhů s využitím identifikace matematických modelů na data pacienta je bilanční metoda absolutní nezbytností.

$V$ literatuře existuje řada poměrně komplikovaných modelů acidobazické rovnováhy [24-29], které ale zatím nenašly praktické uplatnění v klinice. Jsou velmi komplikované a nemohou sloužit jako vodítko k terapii poruch acidobazické rovnováhy. Složité modely jsou často jen jako vědecké výstupy obsahem citovaných článků v časopisech. Autoři někdy tvrdí, jak vytvořili něco pro kliniku, ale často je to jen pouhé konstatování. My bychom chtěli modely vytvářet nejen kvůli článkům v časopisech, ale používat je i prakticky:

- Využívat modely jako simulační trenažéry umožňující krok po kroku sledovat patogenezi nejrůznějších poruch vnitřního prostředí a pohledem "pod kapotu" dát možnost klinikům pochopit co se vlastně při rozvoji dané patogenezi děje. Proto je také našim úsilím vytvořit webově přístupný model s vhodným uživatelským rozhraním.

- Vytvářet modely jako nástroje pro diagnostiku i pro propočítávání korekční terapie. Domníváme se, že velká, zatím nevyužitá informace je nejen v klinicky měřených hodnotách, ale i dynamice odpovědí na vyvolávající stimuly třeba v reakcích na podání infúzí aj.

\section{Literatura}

[1.] Matousek S, Kofranek J, Rees SE. Independence of Variables in Stewart's Model of the Acid-Base Chemistry of the Blood Plasma. IFAC Proceedings Volumes. Elsevier; 2009;42: 246-250.

[2.] Matousek S, Handy J, Rees SE. Acid-base chemistry of plasma: consolidation of the traditional and modern approaches from a mathematical and clinical perspective. J Clin Monit Comput. Springer Netherlands; 2010;25: 57-70.

[3.] Kellum JA. Clinical review: reunification of acid-base physiology. Crit Care. BioMed Central; 2005;9: 500.

[4.] Kamel KS, Halperin ML. Fluid, Electrolyte and Acid-Base Physiology: A Problem-Based Approach. Elsevier Health Sciences; 2016.

[5.] Matoušovic K, Martínek V, Kvapil M. Acidobazická rovnováha těles nl'ych tekutin a její kvantitativní fyzikálně-chemické hodnocení. Aktual Nefrol. 2002;4: 150-156.

[6.] Matoušovic K, Martínek V, Kvapil M. Acidobazická rovnováha tělesných tekutin a její kvantitativní fyzikálně-chemické hodnocení. Aktual Nefrol. 2002:4: 150-156.

[7.] Schück O, Matoušovic K. Vztah mezi pH a diferencí silných iontů (SID) ve vnitřním prostředí. Klin Biochem Metab. nts.prolekare.cz; 2005; Available: http://nts.prolekare.cz/cls/odkazy/kbm0501_32.pdf

[8.] Engliš M, Jabor A, Kubáč P, Červinka I. Př́spěvek k hodnocení metabolické složky poruch acidobazického metabolizmu podle Stewartovy a Fenclovy koncepce. Klin Biochem Metab. 2006;14: 225-227.

[9.] Stewart PA. How to Understand Acid-base: A Quantitative Acid-base Primer for Biology and Medicine. Edward Arnold; 1981.

[10.] Stewart PA. Modern quantitative acid-base chemistry. Can J Physiol Pharmacol. 1983;61: 1444-1461.

[11.] Rossing TH, Maffeo N, Fencl V. Acid-base effects of altering plasma protein concentration in human blood in vitro. J Appl Physiol. 1986;61: 2260-2265.

[12.] McAuliffe JJ, Lind LJ, Leith DE, Fencl V. Hypoproteinemic alkalosis. Am J Med. 1986;81: 86-90. 
[13.] Fencl V, Rossing TH. Acid-base disorders in critical care medicine. Annu Rev Med. 1989;40: 17-29.

[14.] Fencl V, Leith DE. Stewart's quantitative acid-base chemistry: applications in biology and medicine. Respir Physiol. 1993;91: 1-16.

[15.] Figge J, Jabor A, Kazda A, Fencl V. Anion gap and hypoalbuminemia. Crit Care Med. journals.Iww.com; 1998;26: 1807-1810.

[16.] Fencl V, Jabor A, Kazda A, Figge J. Diagnosis of Metabolic Acid-Base Disturbances in Critically III Patients. Am J Respir Crit Care Med. 2000;162: 2246-2251.

[17.] Kofránek J, Matoušek S, Andrlík M. Border flux ballance approach towards modelling acid-base chemistry and blood gases transport. In: Zupanic VB, Karba S, Blažič S, editors. Proceedings of the 6th EUROSIM Congress on Modeling and Simulation, http://www physiome. cz/references/ljubljana2007 pdf. Ljubljana: University of Ljubljana.; 2007. pp. CD Rom Proceedings: TU-1-P7-4: 1-9.

[18.] Kofránek J. Bilanční pojetí acidobazické rovnováhy. Medsoft. 2017;29: 34-56. Online: http://www.creativeconnections.cz/medsoft/2017/Medsoft 2017 Kofranek1.pdf

[19.] Halperin ML, Kamel KS. Some observations on the clinical approach to metabolic acidosis. J Am Soc Nephrol. 2010;21: 894-897.

[20.] Russo MA. Dilutional Acidosis A Nonentity? anesthesiology.pubs. asahq.org. 1997; Available: http://anesthesiology.pubs.asahq.org/ article.aspx?articleid $=1948863$

[21.] Wilkes P. Hypoproteinemia, strong-ion difference, and acid-base status in critically ill patients. J Appl Physiol. 1998;84: 1740-1748.

[22.] Rosenbaum BJ, Makoff DL, Maxwell MH. Acid-base and electrolyte changes induced by acute isotonic saline infusion in the nephrectomized dog. J Lab Clin Med. 1969;74: 427-435.

[23.] Garella S, Tzamaloukas AH, Chazan JA. Effect of isotonic volume expansion on extracellular bicarbonate stores in normal dogs. Am J Physiol. 1973;225: 628-636.

[24.] Wooten EW. Calculation of physiological acid-base parameters in multicompartment systems with application to human blood. J App Physiol. 2003;95: 2333-2344.

[25.] Wooten EW. Strong ion difference theory: More lessons from physical chemistry. Kidney Int. Elsevier; 1998;54: 1769-1770.

[26.] Morgan TJ. Partitioning standard base excess: a new approach.J Clin Monit Comput. 2011;25: 349-352.

[27.] Wolf MB, Deland EC. A mathematical model of blood-interstitial acid-base balance: application to dilution acidosis and acid-base status. J Appl Physiol. 2011;110: 988-1002.

[28.] Wolf MB. Whole body acid-base and fluid-electrolyte balance: a mathematical model. Am J Physiol Renal Physiol. 2013;305: F1118-31.

[29.] Wolf MB. Comprehensive diagnosis of whole-body acid-base and fluid-electrolyte disorders using a mathematical model and whole-body base excess. J Clin Monit Comput. 2015;29: 475-490.

\section{Kontakt}

\section{Jiř́ Kofránek}

Oddělení biokybernetiky a počítačové podpory výuky ÚPF 1. LF UK,

Praha U Nemocnice 5128 53,

Praha 2

e-mail: kofranek@gmail.com 